\title{
Zero-deforestation commitments in Indonesia Governance challenges
}

\author{
Romain Pirard, Sophia Gnych, Pablo Pacheco and Steven Lawry
}

\section{Highlights}

- Zero-deforestation commitments are emerging rapidly in Indonesia. They already encompass a large portion of crude palm oil production and almost all the pulp and paper (P\&P) sector; typically, they reflect the values of the "no-deforestation, no-exploitation (social) and no-peat" policies.

- These commitments depend on definitions of 'forests' for their identification and conservation, which in turn rely on methodologies such as High Conservation Value and High Carbon Stock.

- Early implementation has revealed that the palm oil sector is facing a number of governance challenges to achieve commitments: the legal framework is not systematically supportive of the pledges, and the government promotes a different vision of sustainability. Of note is the fact that the P\&P sector is more advanced.

- Integration of smallholders into sustainable value chains poses another challenge for the palm oil sector: traceability, better environmental performance and improved yields require urgent action. Legalization of smallholder operations is critical and goes beyond commitments, because it determines access to financing and certification, among others.

- To be effective, zero-deforestation commitments must align public and private governance arrangements. This requires an agreement on visions of sustainability supported by public policies; progress on land tenure; enforcement of progressive regulations at national and regional levels; and the implementation of strong policies to rationalize the expansion of small and medium holdings of oil palm.

- Legacy issues must also be addressed for the main palm oil and P\&P groups: land restitution through due processes, support to smallholders and investments in land restoration are some promising avenues worth pursuing.

\section{Introduction}

\section{Pressure from civil society for corporations to strengthen and expand their sustainability commitments}

Globally traded agricultural commodities such as palm oil, soy, pulp and paper (P\&P) and beef have been identified as key drivers of deforestation in tropical forested areas (Gibbs et al. 2010). Several public and private entities have tried to address this issue in Indonesia using a variety of approaches, with mixed results. These include marketbased certification mechanisms such as the Roundtable on Sustainable Palm Oil (RSPO), mandatory standards such as those drafted in the Indonesian Sustainable Palm Oil (ISPO') system, and major policy changes such as the moratorium on plantation concession permits on primary forest areas and peatlands.

1 Peraturan Menteri Pertanian No. 19/Permentan/OT.140/3/2011 tentang Pedoman Perkebunan Kelapa Sawit Berkelanjutan Indonesia/Indonesian Sustainable Palm Oil (Ministry of Agriculture, Jakarta, Indonesia).
"Zero-deforestation" pledges by companies along the supply chain are emerging in this context (see Box 1). These informal but targeted commitments aim to encourage upstream producers to embrace higher sustainability standards, with the ultimate goal of removing deforestation and land rights abuses from supply chains. Many of these pledges extend to no-fire and no-peat policies. Driving this trend are: consumer rejection of goods produced in ways that contribute to negative environmental and social outcomes; NGOs that catalyze these consumer expectations through 'naming and shaming' companies with destructive production practices; and heightened investor awareness of the reputational and market risks associated with commoditydriven deforestation.

\section{Zero-deforestation commitments for the palm oil and pulp and paper sectors in Indonesia} Indonesia is the world's number one producer of palm oil and among the top 10 producers of P\&P. Commitments have multiplied in recent years in the country, where the 
estimated annual forest loss in 2006-2010 was 690,000 ha (Margono et al. 2014) and where forests are under continued threat.

In 2011, Golden Agri-Resources (GAR) made the first high-profile pledge, and this led to a collaboration between GAR, Greenpeace and The Forest Trust, an independent entity in charge of monitoring (Greenpeace 2014; Poynton 2014). This resulted in the High Carbon Stock (HCS) approach, ${ }^{2}$ which then acted as a reference for other pledges (e.g. Wilmar 2013). In 2014, two groups or coalitions of major palm oil producers with overlapping memberships emerged - the Indonesian Palm Oil Pledge (IPOP) and the Sustainable Palm Oil Manifesto (SPOM). These groups have been able to advance the implementation of pledges, both at the country level and internationally. Aside from deforestation, they address social issues explicitly as well as land rights, conflicts and smallholder issues - the latter being a critical aspect of current debates (IPOP 2015).

Both groups are engaged in advertising their pledges, producing knowledge to make progress on implementation, coordinating activities and lobbying. They also work on technical issues, and SPOM sets a good example with its ongoing development of practical guidelines for the identification of potential conservation areas (Nature 2015).

In parallel, the two main P\&P groups operating in Indonesia - Asia Pulp and Paper (APP) and Asia Pacific Resources International Holdings (APRIL) - have announced their own zero-deforestation commitments over the past two years, labeled the Forest Conservation Policy and Sustainable Forest Management Policy, respectively. These policies prohibit plantation concessionaires in charge of supplying mills with fiber from being associated with any forest conversion event, marking a dramatic change from past practices. The policies extend to long-term third-party suppliers, and touch upon social issues and the use of peatland, in line with palm oil sector practices.

\section{Key differences between the palm oil and pulp and paper sectors}

Key differences divide the palm oil and P\&P sectors, and these have strong implications for their ability to deliver on their pledges. The P\&P sector is highly concentrated and vertically integrated, which makes

2 The approach is designed to break the link between deforestation and high-risk commodities, such as palm oil and pulp and paper, by delineating areas that are off limits based on their aboveground carbon stocks and biodiversity (Greenpeace 2014). it easier to control operations on the ground and the associated supply chain. In contrast, the palm oil supply base is made up of a wide range of producers of various sizes (including smallholders), operating across different scales. But fewer than 10 firms dominate the international trade in palm oil, which enables a handful of corporate commitments to cover much of the supply base.

Investment dynamics for both commodities also differ, because while palm oil remains an attractive investment (even in the context of declining prices), the Indonesian Government has struggled to meet national targets for timber plantations: about 2-3 million ha were planted out of the 10 million ha target. Note also that the supply base for the two main P\&P groups is already more or less secured, as they claim that plantations do not need to be expanded any further to supply existing mills. This leaves uncertainty over whether these groups will invest further in plantation estates.

Lastly, oil palm plantations have been established on land outside of the forest estate with explicit agricultural production objectives, whereas timber plantations are subject to forestry laws that are more favorable to conservation.

In this brief, we present some critical challenges for achieving these commitments in Indonesia based on lessons learned from early attempts at implementation. These challenges include misalignment between private and public views and governance arrangements, the integration of smallholders into these progressive policies, and legacy issues. We then highlight promising avenues for overcoming these challenges.

\section{Selected issues affecting implementation}

\section{A conducive legal framework should not be taken for granted}

The commitments were straightforward and raised great expectations as announcements presented a case where companies would be responsible for, and have the capacity to take up the challenge of, making decisions with respect to the management of their concessions. But early implementation attempts within the palm oil sector have shown that the current legal framework in Indonesia could be an impediment to their realization. This misalignment reflects the fact that private commitments go beyond existing regulations, which were issued to encourage the use of abundant natural resources and support the development of an incredibly profitable perennial crop. For example, High Carbon Stock (HCS) and High Conservation Value 


\section{Box 1. Is the zero-deforestation concept a good one?}

The rapid emergence of zero-deforestation commitments encouraged by effective NGO campaigns has been a reaction to a sense of urgency among consumers about saving the remaining tropical forests. Other policies or sustainability standards (e.g. RSPO) were limited by a lack of compliance and enforcement, among other issues. Thus, the zerodeforestation commitments emerged, culminating in the New York Declaration on Forests in September 2014, when a number of governments also committed to end natural forest loss by 2030.

Zero deforestation faces issues such as gross versus net forest loss (i.e. whether deforestation in one location could be compensated for by restoration in another), as well as socioeconomic implications. More generally, it can be questioned from a conceptual point of view.

The concept of zero-deforestation commitments can essentially be understood in two different ways. One is that strict and generalized commitments by companies along the supply chain lead to verifiable indicators of no deforestation for commodity production; the other is that severe deforestation events are gradually removed from the supply chain, at least for the main actors.

The first approach implies that consensually agreed methodologies are systematically applied on the ground in order to avoid any loss of forest cover, which ultimately leads to a halt to deforestation for agricultural development. It relies on methods such as High Carbon Stock (HCS) or High Carbon Value (HCV) in order to actually define a forest and what should in turn be protected from development. The second approach provides a vision of a world where agricultural expansion would spare most valuable natural forests as much as possible, i.e. a vision underlying decisions on where agricultural expansion should take place in order to meet the broader goals of sustainable development. With this broader scope in mind, one could envisage, for instance, differing standards for companies and smallholders, the latter enjoying more lax environmental standards for the sake of pragmatism (it is difficult to avoid forest conversion in practice) and equity (it is assumed that smallholder expansion would contribute more to the livelihoods of the poor).

The zero deforestation concept has encountered resistance from the Indonesian government, which gives two main reasons: (i) these commitments would de facto prevent economic development based on productive land management, and (ii) that smallholders and a number of companies would be put out of business (Jakarta Post 29 August 2015). The authorities promote their own standards, stating that they would guarantee an acceptable level of sustainability without being tied to strict HCV/HCS assessments. In other words, they are concerned that technical assessments made using HCV/HCS would prevail over political objectives and visions of development.

In this context, a major challenge of ongoing debates is to reconcile different approaches that either give priority to commitments with measurable indicators in order to ensure accountability, or that intend to mainstream the very concept of sustainability in directions set by a range of public policies. An overriding issue, in this context, is the fate of the multitude of small- and middle-scale investors - i.e. whether they will be able to operate without becoming trapped in lower-value supply chains.

$(\mathrm{HCV})$ areas set aside under no deforestation and RSPO commitments, respectively, could be withdrawn from company concessions and reallocated (Colchester et al. 2009, 2011).

In addition, companies may have their temporary permits withdrawn if HCS/HCV assessments are not finalized soon enough for the plantation to be established within the legally allocated time frame of three years. Indeed, these assessments rely on extensive fieldwork and are still at an early stage of development and refinement. The government puts pressure on companies willing to undertake sound environmental and social assessments, as exemplified by ISPO certification, that go beyond the existing legal framework. This pressure relies heavily on regulation PP No. 11/2011, which aims at controlling and optimizing "idle land." Agrarian law authorizes the government to issue three warning letters and then revoke the rights of concession holders if land is abandoned or the company fails to use it in line with its allocation. Under National Land Agency (BPN) Regulation No. 4/2010, land is regarded as idle if it is not being used according to the purposes defined in the land right entitlement.

Further, laws and land rights are not fully enforced and fail at preventing encroachment by outsiders even when boundaries are defined legally and based on proper consultation processes with local populations. Two critical 
problems arise: first, "third party" actors keep moving into concessions to clear land for their own livelihoods, with little public action to stop the phenomenon, even when it takes place on areas set aside for the purpose of conservation (Rainforest Alliance 2015); and second, unclear land tenure remains an unsettled issue, with significant overlaps between concessionaires, disputes over land rights, and slow recognition of community land. This long-standing problem in the country, which has large impacts on the sustainable management of forest resources, is being taken very seriously. The One-Map initiative, which gathers all rights and permits into one database to avoid overlaps and improve clarity for the sake of land use planning, is one possible solution.

\section{Impacts on smallholders: Restricted access and market fragmentation}

As far as the palm oil sector is concerned, and leaving aside the case of middle- to large-scale private owners who operate on private land, different business models have evolved linking companies to smallholders. These include a range of nucleus-plasma ${ }^{3}$ models featuring strong contractual ties between both sides - which have traditionally constituted the priority approach by the government - and a variety of independent and semi-independent smallholders that are commonly organized around cooperatives. While nucleus-plasma models tend to deliver higher productivity and economic benefits for smallholders, the independent smallholders model offers more autonomy but lower profits (Molenaar et al. 2013; Suharno et al. 2015). Independent smallholders also tend to underperform in terms of sustainability, have limited knowledge of best management practices, and have limited access to agricultural inputs associated with financial constraints and poor access to markets (Lee et al. 2014). Therefore, zero-deforestation commitments will be easier to implement under the nucleus-plasma model as it enables greater control and builds on a stronger capacity base.

Traceability of produce from independent smallholders also presents a challenge, especially when their produce is delivered to market via an extended network of intermediaries. Commonly, for example,

3 The development of the palm oil industry in Indonesia has traditionally relied on a number of government regulations that require corporate investors to have formal partnerships with people. These partnerships refer to one core plantation (nucleus) and associated smallholder plantations (plasma), with in many cases the company in charge of the management of the planted plots. Benefit sharing mechanisms are in place to make sure that the smallholders receive their share the benefits. Depending on cases, these smallholders (plasma) are locals or migrants, and potentially transmigrants as part of the government policy to move people from overpopulated islands (e.g. Java or Bali) to 'outer islands' (e.g. Sumatra or Borneo) fresh fruit bunches from different sources are mixed in the marketplace, making reliable tracing of the supply chain very difficult. Therefore, there is a risk of marginalizing the poorest smallholders if pledging companies want to avoid the risk of purchasing produce from unsustainable sources.

Viewed positively, however, such corporate commitments could also provide an opportunity to deliver technical and financial support to smallholders and upgrade the supply base for the long term. The alternative is potential market fragmentation (with certain producers limited to supplying unscrupulous markets), smallholder marginalization and continued deforestation. Note that these risks are also addressed by a number of governmental initiatives, e.g. the Sustainable Palm Oil Initiative between the Ministry of Agriculture and the United Nations Development Programme, with one aim being legalization of production by smallholders and improvement of their practices.

\section{Past practices should not be forgotten: The legacy issue}

The issue of legacy is critical and has been underestimated so far. The main groups committing to deforestation-free agriculture have previously been involved in large-scale deforestation, as exemplified by the P\&P sector (Barr 2001; Pirard and Cossalter 2006), as well as in numerous land claims and conflicts (KPMG 2014; Rainforest Alliance 2015). In brief, many of these corporate groups have enjoyed decades of uninhibited access to natural forests of mixed tropical hardwoods, often ignoring legitimate land claims by local people on concessions allocated by the government without due process.

A number of forest conservation and indigenous rights groups object to the premise that recent zerodeforestation commitments may absolve or excuse past destructive practices, particularly because past behaviors have enabled corporate groups to gain control of vast areas of land - for example, APP controls 2.6 million ha of concessions and APRIL about 1 million ha. In the past, corporate groups took advantage of laws skewed in their favor, which were neither fair nor appropriate from an environmental or social point of view.

\section{Avenues to overcome challenges}

\section{Toward a harmonization of governance arrangements between the public and private sectors}

The interactions and roles of consumers, civil society and investors in support of sustainable land use 
practices potentially constitute "emerging nonstate governance arrangements." As such, they represent a major challenge to traditional, statecentric governance of forest land use in Indonesia. Importantly, non-state arrangements are prescribing new, higher standards of forested land use and conservation than those prescribed by state regulatory bodies, which represents a clear challenge to the state's hegemony to establish standards.

Recent public statements by government officials in Indonesia objecting to zero-deforestation pledges (because, among other reasons, a number of smallholders and companies are being denied access to markets, by "clean" traders) indicate a level of discomfort with the idea that aspects of land use within concessions can be governed by actors other than the state.

Initiatives for conserving forests, driven by the interplay of non-state interests, clearly have the potential to fundamentally alter forest governance, with farreaching, positive implications for forest conservation and better social outcomes. But their success in the long term will require acceptance by states that non-state actors have a legitimate role to play as 'co-governors'. While this framework will be difficult for some to accept, the consequences of rejecting it (lost access to global commodity markets) may be a bigger price to pay.

A dialogue between stakeholders on agendas important to all parties could help support the development of new governance arrangements. For example, the Indonesian Government's commitments to greenhouse gas $(\mathrm{GHG})$ emissions reductions from land use and the potential positive impacts of zerodeforestation commitments could be a bridging point. Other useful topics for discussion are the need to: upgrade and certify smallholders under the Ministry of Agriculture's ISPO standard; develop traceability systems in order to include them under zero-deforestation commitments; and improve spatial and agrarian planning capacities at the provincial and district levels that can help resolve legal conflicts over $\mathrm{HCV}$ and HCS land allocations. Many of these issues are the responsibility of different sectoral ministries, and are therefore usually addressed independently.

\section{Investing in supporting smallholders through inclusive business models}

Establishing smallholder-inclusive business models constitutes a crucial part of corporate efforts to achieve zero deforestation and to garner support from government. Including smallholders in deforestation- free supply chains may provide considerable benefits, as social considerations (e.g. no exploitation) form a part of corporate commitments and smallholders may receive active support in achieving better practices in line with new standards. Better practices imply lower environmental impacts, but are also likely to translate into higher yields with positive impacts on smallholder livelihoods. Yet the other side of the coin could be that companies have excessive control over the smallholders, with low prices paid because of a lack of alternative marketing channels.

Several initiatives have already developed recommendations for best practices that include capacity building and yield improvements. The urgent action needed from companies includes investments in mechanisms for enhanced technical assistance, access to inputs such as fertilizers, and greater access to financial services such as loans. These actions should occur under more transparent contracts between companies, intermediaries and independent smallholders.

Farmer groups must also be strengthened to improve flows of information and knowledge sharing vertically along the supply chain and horizontally across the supply base. It is also necessary to invest in training, incentives, and monitoring and traceability systems that are adapted to local conditions, to ensure that smallholders, especially independent ones, comply with sustainability requirements. These actions will reduce the risk of exclusion and market fragmentation, while increasing farmers' productivity and long-term economic sustainability.

\section{Addressing legacy with land restitution to communities and investments in forest restoration}

A balance needs to be struck between rewarding historic deforesters for successfully implementing deforestation-free policies and holding them accountable for their past actions. One option is to encourage investment in restoration. This is all the more desirable now that the government has created the system of Ecosystem Restoration Concessions, which allows companies to manage degraded areas in order to restore their productivity and ecosystem services (the two main P\&P groups APP and APRIL have already invested in such concessions). APP's 1 million ha forest conservation program, currently at the design stage, aims to involve stakeholders in a number of landscapes around its concessions in order to achieve the conservation objectives at a landscape level, beyond the areas controlled by the group. The prospects of such initiatives deserve to be assessed 
in terms of their relevance within formal zerodeforestation commitments. The potential to include similar initiatives in the palm oil sector also needs reflection by civil society groups as well as companies. It is worth noting that there is already a tried and tested compensation mechanism under the RSPO to deal with companies that caused deforestation (primary forest) after the 2007 cut-off date.

Another complementary option would be to address social issues as well, by requiring land restitution when communities have been deprived of their rights to land over the course of development of plantations. This means that companies should not only follow Free and Prior Informed Consent (FPIC) processes when developing new lands, but also engage in substantial efforts to solve remaining conflicts. The uncertain status of land tenure in Indonesia, combined with violent enforcement of concession licenses, and the dynamics of migration within the country, has resulted in an abundance of community conflicts, ancestral rights being violated, and excessive land speculation by migrants taking advantage of poor law enforcement. The key now is to design and apply methods that help distinguish between legitimate and abusive claims in order to allow companies to operate while still providing people with the rights they deserve.

\section{Conclusions}

\section{Zero-deforestation commitments cannot be stand-alone private strategies}

The momentum generated by recent corporate zerodeforestation commitments is promising. However, to capitalize on this momentum and capture the resources becoming available for greening the palm oil and P\&P sectors, a number of challenges must be acknowledged and resolved in order to ensure effectiveness and equity. First and foremost, the Indonesian Government will need to buy in to the movement and work with the private sector and civil society at all levels. Government development plans, such as the 2005-2025 RPJPN (National LongTerm Development Plan) and the Green Growth Framework for Indonesia developed by the National Development Planning Agency, BAPPENAS, already places considerable emphasis on private investment, both domestic and foreign, as well as privatesector standards and certification as tools to drive sustainable development.
However, engrained political agendas and conflicting objectives for development at the government level have resulted in a partial misalignment between the legal framework and zero-deforestation commitments, which risks leading to suboptimal implementation on the ground. This observation holds specifically for the palm oil sector under the responsibility of the Ministry of Agriculture. This sector has bright prospects for further growth, associated revenues for the state and job creation for the country. In contrast, the P\&P sector operates under the more stringent forestry laws and has witnessed much more limited investor interest, thereby precluding it from expanding in the immediate future.

Evidence of contradictions between laws, regulations and pledges exist already for palm oil, and there is a long way to go until the public and private actors stand side-by-side with a common vision of sustainability. Tensions exist and domestic debates highlight rural development, energy self-sufficiency and sovereignty as prevailing objectives in the expansion of the palm oil sector. Yet other public policy objectives such as reduced GHG emissions or Aichi Targets within the Convention on Biological Diversity might also serve as arguments for supporting the zero-deforestation movement.

\section{Smallholders and land tenure must be addressed for sustainable, equitable and effective outcomes}

An increasingly important issue in this debate is the role and fate of smallholders. This challenge is often used as justification by the government in its opposition to the pledges made in the palm oil sector. The risk of marginalizing the poorest, independent oil palm smallholders cannot be neglected. Exclusion of independent smallholders from deforestation-free supply chains would not only result in further impoverishment, but also in environmental damage through leakage effects. Note that smallholders are close to nonexistent in the P\&P sector, where risks are different. The main issue for sustainability commitments in the P\&P sector is more one of law enforcement in order to prevent significant encroachment in pulpwood plantation concessions.

The responsibility for a better integration of oil palm smallholders does not lie solely in the hands of companies. The government is already taking action to improve and legalize practices in a context where, admittedly, state support remains insufficient. Intensive research to analyze the smallholder dynamics, identify areas of expansion, and craft the right modes of intervention, is ongoing. 


\section{References}

Barr C. 2001. Banking on sustainability: Structural adjustment and forestry reform in post-Suharto Indonesia. Washington, DC: World Wide Fund for Nature (WWF) Macroeconomics Program Office, and Center for International Forestry Research (CIFOR). Accessed 6 November 2015. http://www.cifor.org/ library/982/banking-on-sustainability-structuraladjustment-and-forestry-reform-in-post-suhartoindonesia/?pub=982

Colchester M, Jiwan N, Anderson P, Darussamin A and Kiky A. 2011. Securing High Conservation Values in Central Kalimantan: Report of the Field Investigation in Central Kalimantan of the RSPO Ad Hoc Working Group on High Conservation Values in Indonesia. 6 July. Kuala Lumpur: Roundtable on Sustainable Palm Oil.

Colchester M, Anderson P, Jiwan P, Andiko and Mei Toh S. 2009. Report of an independent investigation into the effectiveness of the application of high conservation value zoning in palm oil development in Indonesia. Forest Peoples Programme, HuMa, Sawit Watch and Wild Asia.

Gibbs HK, Ruesch AS, Achard F, Clayton MK, Holmgren P, Ramankutty N and Foley JA. 2010. Tropical forests were the primary sources of new agricultural land in the 1980s and 1990s. Proceedings of the National Academy of Sciences of the United States of America 107(38):16732-37.

Greenpeace. 2014. The HCS approach: No deforestation in practice. Accessed 21

September 2015. http://www.greenpeace.org/ international/Global/international/briefings/ forests/2014/HCS\%20Approach_Breifer_March2014.pdf [IPOP] Indonesian Palm Oil Pledge. About Indonesian palm oil pledge. Accessed 7 November 2015. http:// www.palmoilpledge.id/

KPMG. 2014. APRIL SAC: Specified auditing procedures on SFM Policy Implementation. KPMG.

Lee JSH, Abood S, Ghazoul J, Barus B, Obidzinski K and Koh LP. 2013. Environmental impacts of large-scale oil palm enterprises exceed that of smallholdings in Indonesia. Conservation Letters 7(1):25-33.

Margono BA, Potapov PV, Turubanova S, Stolle F and Hansen MC. 2014. Primary forest loss in Indonesia over 2000-2012, Nature Climate Change.

Molenaar JW, Persch-Orth M, Lord S, Taylor C and Harms J. 2013. Diagnostic study on Indonesian oil palm smallholders: Developing a better understanding of their performance and potential, Global Sustainability Associates - Aid Environment Triodos Facet.

Nature. 29 July 2015. Tropical protection (editorial). Nature 523: 501. doi:10.1038/523501a

Nepstad D, McGrath D, Stickler C, Alencar N, Azevedo A, Swette B, Bezerra T, DiGiano M, Shimada J, Seroa da Motta R et al. 2014. Slowing Amazon deforestation through public policy and interventions in beef and soy supply chains. Science 344(6188):1118-23.

Pirard R and Cossalter C. 2006. The Revival of Industrial Forest Plantations in Indonesia's Kalimantan Provinces. Will they help eliminate fiber shortfalls at Sumatran pulp mills or feed the China market? CIFOR Working Paper No. 37. Bogor, Indonesia: Center for International Forestry Research (CIFOR).

Poynton S. 29 January 2014. Wilmar's "No deforestation" goal could revolutionize food production. The Guardian. Accessed 29 January 2015.

Rainforest Alliance. 2015. An Evaluation of Asia Pulp \& Paper's Progress to Meet its Forest Conservation Policy (2013) and Additional Public Statements. Period Covered: 1 February 2013 to 15 August 2014. Jakarta.

[RSPO] Roundtable on Sustainable Palm Oil. 2014. Roundtable on sustainable palm oil impact report 2014. Malaysia: Roundtable on Sustainable Palm Oil.

[Wilmar] Wilmar International Limited. 2013. No Deforestation, No Peat, No Exploitation Policy. Accessed 02 February 2015. http://www.wilmarinternational.com/wp-content/uploads/2012/11/ No-Deforestation-No-Peat-No-Exploitation-Policy.pdf 

Tropical Agriculture and the World Agroforestry Centre.
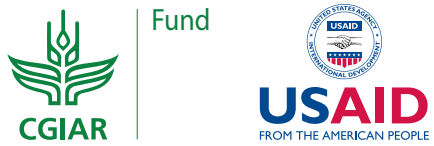

Preparation of this infobrief was supported by USAID funding for CIFOR's Governing Oil Palm Landscapes for Sustainability (GOLS) project. 